\title{
Feto-maternal outcome in patients with HELLP and partial HELLP syndrome: a prospective 10 year study in Shri Guru Ram Rai Institute of Medical and Health Sciences, Uttarakhand, India
}

\author{
Archna Tandon*, Priyanka Chaudhari, Vineeta Gupta, Monika Ramola
}

Department of Obstetrics and Gynaecology, SGRRIM and HS, Dehradun, Uttarakhand, India

Received: 08 July 2016

Accepted: 05 August 2016

*Correspondence:

Dr. Archna Tandon,

E-mail: archnatandon@gmail.com

Copyright: (c) the author(s), publisher and licensee Medip Academy. This is an open-access article distributed under the terms of the Creative Commons Attribution Non-Commercial License, which permits unrestricted non-commercial use, distribution, and reproduction in any medium, provided the original work is properly cited.

\begin{abstract}
Background: The acronym HELLP was coined by Loise Weinstein in 1982 to describe a syndrome consisting of hemolysis (H) elevated liver enzyme (EL) and low platelets (LP). The purpose of the study was to detect and evaluate the feto maternal outcome of HELLP and partial HELLP syndrome among preeclamptic patients.

Methods: Study analyzed fetal and maternal outcome in 110 patients with HELLP syndrome and 89 patients with partial HELLP Syndrome and compared with 1100 patients of preeclampsia only.

Results: 1210 patients were included in this study. Out of these patients HELLP syndrome, partial help syndrome and preeclampsia were $10 \%$ and $7.3 \%$ and $82.7 \%$. The systolic BP, gestational age at admission and at delivery, hematological and biochemical parameters, vaginal delivery and type of anesthesia were significantly different in HELLP syndrome and partial HELLP syndrome than in pre eclampsia group. There was significant difference in perinatal outcome like birth weight, IUD, neonatal death and NICU-admissions. Eclampsia was significantly increased in HELLP syndrome and partial HELLP syndrome.

Conclusions: HELLP and partial HELLP syndrome must be diagnosed as soon as possible. Partial HELLP and HELLP syndrome are equally dangerous. HELLP Syndrome is severe then preeclampsia in terms of maternal and perinatal outcome.
\end{abstract}

Keywords: HELLP syndrome, Partial HELLP syndrome, Preeclampsia

\section{INTRODUCTION}

The acronym HELLP was coined by Loise Weinstein in 1982 to describe a syndrome consisting of hemolysis $(\mathrm{H})$, elevated liver enzyme (EL) and low platelets (LP). Some experts consider it as a severe form of preeclampsia, while other believes that HELLP syndrome and preeclampsia are separate disorders with overlapping features. As many as $15-20 \%$ of the patients with HELLP syndrome do not have antecedent hypertention or protienurea. ${ }^{6}$

\section{Complete HELLP syndrome}

- Hemolyis-characteristic peripheral blood smear, decreased $\mathrm{Hb}$ and hematocrit, total bilirubin $>1.2 \mathrm{mg} / \mathrm{dl}$

- Elevated liver enzymes-serum laclate dehydrogenase $(\mathrm{LDH})>600 \mathrm{IU} / \mathrm{L}$ aspartate aminotransferase (AST) $>70 \mathrm{IU} / \mathrm{L}$, alanine aminotransfarase (ALT) >50 IU/L.

- Low platelet count platelets $<150,000$.

Presenting symptoms of HELLP syndrome include epigastric or right upper quadrant abdominal pain (65\%), 
nausea and vomiting 50\%, malaise $90 \%$ and non-specific viral syndrome like symptoms.

Table 1: Sign and symptoms of HELLP syndrome.

\begin{tabular}{|l|l|}
\hline Sign and symptoms & Percentage \\
\hline Malaise & $90 \%$ \\
\hline $\begin{array}{l}\text { Right upper quadrant/epigastric } \\
\text { tenderness }\end{array}$ & $90 \%$ \\
\hline Proteinuria & $87 \%$ \\
\hline Hypertension & $85 \%$ \\
\hline Right upper quadrant/epigastric pain & $65 \%$ \\
\hline Headache & $60 \%$ \\
\hline Nausea vomiting & $36 \%$ \\
\hline Visual changes & $17 \%$ \\
\hline Bleeding & $09 \%$ \\
\hline Asitis & $08 \%$ \\
\hline Jaundice & $05 \%$ \\
\hline Shoulder or neck pain & $05 \%$ \\
\hline Pulmonary edema & $6 \%$ \\
\hline
\end{tabular}

\section{Partial HELLP syndrome}

Pregnant women with preeclampsia do not always present the full picture of HELLP syndrome but there are changes in hematological indices and or liver function which adversely affect feto-maternal outcome. Sub-types of HELLP syndrome.

\section{Depending upon laboratory abnormalities}

1. Mississippi classification

A. Class 1 (most severe)

- $\quad$ Platelets $<50,000$

- $\mathrm{AST}$ or $\mathrm{AlT}>70 \mathrm{IU} / \mathrm{L}$

- $\mathrm{LDH}>600 \mathrm{IU} / \mathrm{L}$

B. Class 2

- $\quad$ Platelets 50,000-1,00,000

- $\mathrm{AST}$ or ALT >70 IU/L

- $\mathrm{LDH}>600 \mathrm{IU} / \mathrm{L}$

C. Class 3 (least severe)

- Platelets 1,00,000-1,50,000

- $\mathrm{AST}$ or ALT > $40 \mathrm{IU} / \mathrm{L}$

- $\mathrm{LDH}>600 \mathrm{IU} / \mathrm{L}$

2. Tennessee classification

A. True or complete

- $\quad$ Platelets $<1,00,000$

- $\mathrm{AST}>70 \mathrm{IU} / \mathrm{L}$

- $\mathrm{LDH}>600 \mathrm{IU} / \mathrm{L}$
B. Partial or incomplete Severe pre-eclampsia with any one of the following: ELLP, HEL, EL, LP

ELLP: Absence of hemolysis; HEL. Absence of low platelets; EL: Elevated liver enzymes LP: low platelets. ${ }^{1}$

Any pregnant patient with epigastric or right upper quadrant abdominal pain in the second half of pregnancy, particularly if in association with nausea and or vomiting has HELLP Syndrome until proven otherwise. ${ }^{2}$

The category of women with at least two features of complete HELLP syndrome, are separately detected

The purpose of this study is to compare maternal and perinatal outcome among women with HELLP syndrome, partial HELLP syndrome and women with preeclampsia.

\section{METHODS}

The Study was conducted over a period of 10 years in the department of obstetrics and gynecology, Shri Guru Ram Rai Institute of Medical and Health sciences Dehradun, Uttarakhand which is a tertiary level hospital and medical college. After obtaining ethical approval 1210 patients were included in this study who comprised of antenatal patients attending outpatient department, admitted from emergency, admitted in antenatal ward as booked patients or referred from outside. Inclusion criteria include Blood pressure 140/90 or more and proteinuria of $300 \mathrm{mg} / 24$ hours or more after 20 weeks of pregnancy for preeclampsia group. For HELLP syndrome group above mentioned abnormal laboratory parameters along with criteria for preeclampsia. For partial HELLP syndrome at least two above mentioned abnormal parameters of HELLP with criteria for preeclampsia

Exclusion criteria included known heart disease leading to hypertension, essential hypertension, renal disease, and previous history of jaundice or liver disease, coarctation of aorta, pheochromocytoma and systemic lupus erythromatosus. The Patients were subjected to detailed history, clinical examinations and investigations. Patients were categorized into 3 groups:

- Patients with preeclampsia having the features of HELLP syndrome

- Patients with preeclampsia having only partial HELLP syndrome

- Patients with preeclampsia without the features of complete HELLP syndrome or partial HELLP syndrome.

Following parameters were assessed: maternal age, parity, gestational age at the time of admission, gestational age at delivery, systolic blood pressure, diastolic blood pressure, laboratory parameters like $\mathrm{Hb} \%$, packed cell volume, bilirubin levels, peripheral blood smear, platelet count, LDH level, AST levels ALT levels, 
maternal complications, mode of delivery, type of anesthesia, placental changes. The following perinatal factors were analyzed: birth weight, Apgar score at $1 \mathrm{~min}$ of birth, NICU admission and neonatal complications.

\section{RESULTS}

Total 1210 patients were included in study. Out of 1210 cases 1100 were pre eclampsia and 110 cases were HELLP Syndrome. Out of 110 cases complete HELLP syndrome were found in 21 cases and remaining 89 patients presented partial HELLP syndrome Table 2 and 3 one showing distribution of HELLP syndrome, Partial
HELLP syndrome and preeclampsia, according to maternal age, parity, SBP, DBP, gestational age on admission and delivery, number of booked cases and laboratory parameters. No significant difference in age and parity were found among the HELLP syndrome partial HELLP syndrome and preeclampsia group. Majority of patients in all three groups did not present with severe hypertension. Both the systolic and diastolic blood pressure was higher in HELLP syndrome group than preeclampsia group. Gestational age on admission and delivery in patients with HELLP and partial HELLP syndrome were found to be significantly less than in patients with pre eclampsia.

Table 2: Distribution of patients according to various parameters.

\begin{tabular}{|c|c|c|c|c|c|}
\hline Various parameters & $\begin{array}{l}\text { Preeclampsia } \\
(\mathrm{n}=1100)\end{array}$ & $\begin{array}{l}\text { HELLP } \\
\text { syndrome } \\
(\mathrm{n}=110)\end{array}$ & $\begin{array}{l}\text { P value } \\
\text { (between PE } \\
\text { and HS) }\end{array}$ & $\begin{array}{l}\text { Partial HELLP } \\
\text { syndrome } \\
(\mathrm{n}=89)\end{array}$ & $\begin{array}{l}\text { P value } \\
\text { (between PE } \\
\text { and PHS) }\end{array}$ \\
\hline Age (in years) & $23.6 \pm 4.19$ & $23.6 \pm 4.2$ & 0.91 & $24.2 \pm 4.75$ & 0.61 \\
\hline \multicolumn{6}{|l|}{ Parity } \\
\hline Primi & $667(66.55 \%)$ & $70(63.64 \%)$ & \multirow{2}{*}{0.422} & $59(66.55 \%)$ & \multirow{2}{*}{0.816} \\
\hline Multi & $433(33.45 \%)$ & $40(36.36 \%)$ & & $30(33.45 \%)$ & \\
\hline SBP(in $\mathrm{mm}$ of $\mathrm{Hg}$ ) & $168.2 \pm 14.12$ & $178.6 \pm 15.12$ & 0.02 & $178.3 \pm 15.18$ & 0.14 \\
\hline $\mathrm{DBP}($ in $\mathrm{mm}$ of $\mathrm{Hg}$ ) & $104.6 \pm 5.07$ & $107.3 \pm 7.26$ & 0.02 & $106.6 \pm 7.07$ & 0.14 \\
\hline GA on admission & $\begin{array}{l}36 \text { weeks } 3 \text { days } \\
\pm 2 \text { weeks } 2 \text { days }\end{array}$ & 35 week \pm 2 weeks & 0.01 & 35 week \pm 3 weeks & .04 \\
\hline GA at delivery & $\begin{array}{l}36 \text { weeks } 4 \text { days } \\
\pm 2 \text { weeks }\end{array}$ & $\begin{array}{l}35 \text { weeks } \pm 3 \\
\text { weeks }\end{array}$ & 0.00 & $\begin{array}{l}35 \text { week } \pm 3 \text { weeks } \\
2 \text { days }\end{array}$ & 0.003 \\
\hline Booked cases & $823(74.82 \%)$ & $70(63.64 \%)$ & 0.001 & $38(42.69 \%)$ & 0.016 \\
\hline
\end{tabular}

Table 3: Laboratory parameters of the various groups.

\begin{tabular}{|llllll|}
\hline $\begin{array}{l}\text { Laboratory } \\
\text { parameters }\end{array}$ & $\begin{array}{l}\text { Preeclampsia } \\
(\mathrm{n}=1100)\end{array}$ & $\begin{array}{l}\text { HELLP } \\
\text { syndrome } \\
(\mathrm{n}=110)\end{array}$ & $\begin{array}{l}\text { P value } \\
\text { (between } \\
\text { PE and HS) }\end{array}$ & $\begin{array}{l}\text { Partial HELLP } \\
\text { syndrome } \\
(\mathrm{n}=89)\end{array}$ & $\begin{array}{l}\text { P value } \\
\text { (between PE } \\
\text { and PHS) }\end{array}$ \\
\hline $\mathrm{Hb}(\mathrm{gm} \%)$ & $10.4 \pm 1.21$ & $9.1 \pm 1.21$ & 0.00007 & $9.3 \pm 1.31$ & 0.005 \\
\hline $\mathrm{PCV}(\%)$ & $32.4 \pm 2.6$ & $23.8 \pm 4.22$ & 0.000 & $25.2 \pm 3.08$ & 0.005 \\
\hline Platelet count $(\mathrm{cmm})$ & $263449 \pm 80021.31$ & $160590 \pm 55000$ & 0.000 & $185534 \pm 78218.14$ & 0.002 \\
\hline LDH $(\mathrm{u} / \mathrm{I})$ & $892 \pm 349.3$ & $1016.4 \pm 383.7$ & 0.000 & $986.1 \pm 236.3$ & 0.000 \\
\hline Total bilirubin $(\mathrm{mg} / \mathrm{dl})$ & $0.8 \pm .45$ & $2.6 \pm 1.51$ & 0.000 & $2.3 \pm 1.53$ & 0.000 \\
\hline AST $(\mathrm{u} / \mathrm{I})$ & $58.3 \pm 10.03$ & $148.2 \pm 73.00$ & 0.000 & $144.8 \pm 70.3$ & 0.000 \\
\hline AlT $(\mathrm{u} / \mathrm{I})$ & $41 \pm 6.43$ & $148.3 \pm 70.80$ & 0.000 & $143.5 \pm 66.67$ & 0.000 \\
\hline
\end{tabular}

Table 4: Distribution of preeclampsia, HELLP syndrome (complete and paritial) and partial HELLP syndrome, according to H, HLP, HEL, ELLP.

\begin{tabular}{|c|c|c|c|c|c|}
\hline \multicolumn{6}{|c|}{ Distribution of preeclampsia } \\
\hline Haemolysis in peripheral blood smear & $126(11.51 \%)$ & $75(68.18 \%)$ & 0.001 & $50(56.25 \%)$ & 0.001 \\
\hline Haemolysis and low platelet count & & & & $2(2.247 \%)$ & \\
\hline Haemolysis and elevated liver enzymes & & & & $30(33.70 \%)$ & \\
\hline Low platelet count and elevated liver en & & & & $7(7.86 \%)$ & \\
\hline
\end{tabular}


Booked cases in both HELLP syndrome (63.64\%) and partial HELLP syndrome $(42.69 \%)$ were found to be significantly less than in patients with preeclampsia $(74.82 \%)$
The laboratory parameters in HELLP and partial HELLP syndrome were found to be significantly different than preeclampsia group.

Table 5: Mode of delivery in various groups.

\begin{tabular}{|llllll|}
\hline Mode of delivery & $\begin{array}{l}\text { Preeclampsia } \\
(\mathrm{n}=1100)\end{array}$ & $\begin{array}{l}\text { HELLP } \\
\text { syndrome } \\
(\mathrm{n}=110)\end{array}$ & $\begin{array}{l}\text { P value } \\
\text { (between PE } \\
\text { and HS) }\end{array}$ & $\begin{array}{l}\text { Partial HELLP } \\
\text { syndrome } \\
(\mathrm{n}=89)\end{array}$ & $\begin{array}{l}\text { P value (between } \\
\text { PE and PHS) }\end{array}$ \\
\hline CS & $824(74.82 \%)$ & $80(72.72 \%)$ & 0.422 & $61(68.63 \%)$ & 0.559 \\
\hline Emergency & $708(64.36 \%)$ & $80(72.72 \%)$ & 0.137 & $61(68.63 \%)$ & 0.367 \\
\hline Elective & $116(10.55 \%)$ & 0 & & 0 & \\
\hline VD & $276(25.09 \%)$ & $30(27.26 \%)$ & 0.028 & $28(31.46 \%)$ & 0.007 \\
\hline Spontaneous & $95(8.63 \%)$ & 0 & 0.029 & 0 & \\
\hline Induced & $181(16.19 \%)$ & $30(27.27 \%)$ & & $28(31.46 \%)$ & \\
\hline
\end{tabular}

Table 6: Type of anaesthesia.

\begin{tabular}{|c|c|c|c|c|c|}
\hline Type of anaesthesia & $\begin{array}{l}\text { Preeclampsia } \\
(\mathrm{n}=1100)\end{array}$ & $\begin{array}{l}\text { HELLP } \\
\text { syndrome } \\
(\mathrm{n}=110)\end{array}$ & $\begin{array}{l}\text { P value } \\
\text { (between PE } \\
\text { and HS) }\end{array}$ & $\begin{array}{l}\text { Partial HELLP } \\
\text { syndrome } \\
(\mathrm{n}=89)\end{array}$ & $\begin{array}{l}\text { P value } \\
\text { (between PE } \\
\text { and PHS) }\end{array}$ \\
\hline Spinal anaesthesia & $760(69.09 \%)$ & $45(56.25 \%)$ & \multirow{2}{*}{$<0.001$} & $39(63.93 \%)$ & \multirow{2}{*}{0.011} \\
\hline General anaesthesia & $63(5.73 \%)$ & $35(43.75 \%)$ & & $22(24.71 \%)$ & \\
\hline
\end{tabular}

Table 7: Characteristics of preeclampsia, HELLP syndrome and partial HELLP syndrome according to macroscopic features of placenta.

\begin{tabular}{|c|c|c|c|c|c|}
\hline Macroscopic picture & $\begin{array}{l}\text { Preeclampsia } \\
(\mathrm{n}=1100)\end{array}$ & $\begin{array}{l}\text { HELLP } \\
(\mathbf{n}=\mathbf{1 1 0})\end{array}$ & $\begin{array}{l}\text { Partial } \\
\text { HELLP } \\
(\mathrm{n}=\mathbf{8 9})\end{array}$ & $\begin{array}{l}\mathbf{P} \text { value between } \\
\mathrm{PE} \text { and } \mathrm{H}\end{array}$ & \\
\hline Abruption & $22(2 \%)$ & $52(47.27 \%)$ & \multirow{3}{*}{0.562} & $11(12.4 \%)$ & \multirow{3}{*}{0.363} \\
\hline Calcification & $117(10.63 \%)$ & $52(47.27 \%)$ & & $11(12.5 \%)$ & \\
\hline Infarction & $18(1.63 \%)$ & $4(9.09 \%)$ & & $2(6.25 \%)$ & \\
\hline
\end{tabular}

Table 8: Perinatal outcome.

\begin{tabular}{|llllll|}
\hline & \multicolumn{5}{c}{ Perinatal outcome } \\
\hline BW (in gm) & $2474.5 \pm 425.32$ & $1813 \pm 628.86$ & 0.000 & $2020 \pm 666.63$ & 0.0047 \\
\hline Apgar score (at 1 mn) & $5.3 \pm 2.72$ & $5 \pm 2.59$ & 0.139 & $5.2 \pm 2.52$ & 0.28 \\
\hline IUD & $24(2.18 \%)$ & $20(18.18 \%)$ & 0.003 & $18(20.22 \%)$ & 0.009 \\
\hline IUGR & $208(18.9 \%)$ & $26(23.63 \%)$ & 0.412 & $22(25 \%)$ & 0.337 \\
\hline Neonatal Death & $13(1.17 \%)$ & $34(37.4 \%)$ & 0.001 & $11(12.57 \%)$ & 0.038 \\
\hline Admission in NICU & $297(27 \%)$ & $75(68.18)$ & 0.001 & $55(62.1 \%)$ & 0.011 \\
\hline
\end{tabular}

In patients with partial HELLP syndrome $2.25 \%$ had hemolysis and low platelet counts while $56.25 \%$ had hemolysis and $33.70 \%$ had hemolysis and elevated liver enzymes $7.86 \%$ had low platelet counts (Table 4 ).

In Table 5 and 6 shows characteristics of HELLP syndrome, partial HELLP syndrome and preeclampsia according to mode of delivery, type of anaesthesia, naked eye features of placenta, perinatal and maternal outcome. Majority of patients in all three groups underwent caesarian section. Emergency caesarian sections were more than elective caesarian section in all three groups.
There were no statistically significant differences among the three groups.

Spontaneous vaginal delivery rate were less than induced patients in all categories. Patient with HELLP syndrome and partial HELLP syndrome mostly underwent general anaesthesia during caesarian section but spinal anaesthesia was predominant in preeclampsia group. Rate of spinal anaesthesia were significantly less in HELLP syndrome $(40.00 \%)$. 
Table 9: Maternal complications.

\begin{tabular}{|c|c|c|c|c|c|}
\hline \multicolumn{6}{|c|}{ Maternal complications } \\
\hline Eclampsia & $79(7.18 \%)$ & $40(44.30)$ & 0.001 & $28(31.46 \%)$ & 0.008 \\
\hline MOD & $39(3.54 \%)$ & $9(8.18 \%)$ & & $6(6.74 \%)$ & \\
\hline ARF & $43(3.90 \%)$ & $20(18.18 \%)$ & & $11(12.35 \%)$ & \\
\hline Placental abruption & $23(2.09 \%)$ & $14(12.72 \%)$ & & $11(12.35 \%)$ & \\
\hline DIC & $23(2.10 \%)$ & $10(9.09 \%)$ & & $5(5.61 \%)$ & \\
\hline Sepsis & $35(3.18 \%)$ & $10(9.09 \%)$ & & $5(5.617 \%)$ & \\
\hline Death & $10(0.90 \%)$ & $20(18.18 \%)$ & & $5(5.617 \%)$ & \\
\hline
\end{tabular}

Table 10: Onset of complications.

\begin{tabular}{|llll|}
\hline \multicolumn{4}{c}{ Onset of complications } \\
\hline Antepartum & $120(11.09 \%)$ & $30(27.27 \%)$ & $22(24.70 \%)$ \\
\hline Postpartum & $47(4.2 \%)$ & $26(23.66 \%)$ & $28(31.20 \%)$ \\
\hline
\end{tabular}

\section{DISCUSSION}

HELLP Syndrome was diagnosed in 1982 but controversies present regarding the diagnosis and prognosis of this disease. This study used laboratory criteria for diagnosis of the disease. Partial HELLP Syndrome may be missed or underestimated by the treating doctor.

According to the study prevalence of the complete HELLP syndrome is $1.73 \%$, partial HELLP Syndrome with preeclampsia is $7.3 \%$ and preeclampsia is 91.6. Abbade JF et al found the complete HELLP 1.8\%, Partial HELLP $12.9 \%$, preeclampsia $47.1 \%{ }^{3}$ Results are comparable to the study.

According to study by Guzel AI et al HELLP syndrome was $0.6 \%$. The results are not comparable to the study. The reason may be the most of the patients in the study were primigravida and less than 24 years old. Similar results were reported by Rashid A et al.

Mean diastolic BP for partial HELLP syndrome was 104.6 \pm 5.01 , 107.3 \pm 7.26 respectively. Even though HELLP Syndrome considered being a variant of severe Eclampsia its severity is reflected in its laboratory parameters. But not in the usual clinical parameter of Blood Pressure that typical reflects disease severity of preeclampsia. This is similar to the findings of Hemant $S$ et al and Heram K et al. ${ }^{6,9}$

Caesarian Section rate in HELLP was very high in the study as pregnancy was terminated as soon as disease was diagnosed to avoid worsening of condition. This resulted in increased in cesarean section rate and preterm delivery. In our study cesarean section rate in preeclampsia, HELLP and partial HELLP is respectively $74.82 \%, 72.72 \%, 68.63 \%$ with a $p$ value of 0.669 , thereby ruling out any significant difference among the value.
The results are comparable with Rakshit A et al and Rath $\mathrm{W}$ et al. ${ }^{5,7}$

Women with partial HELLP syndrome have significant maternal and perinatal complications which are almost as dangerous as in HELLP syndrome. It emphasizes the importance of recognizing HELLP and partial HELLP syndrome as distinct entity which are associated with serious maternal and perinatal complications.

Present study showing significantly increased incidence of eclampsia in HELLP syndrome group and partial HELLP syndrome than that in preeclampsia .similar results are documented by Rakshit et al and Aydin $\mathrm{S}$ et al. ${ }^{5,8}$ Placental findings seen with bad perinatal prognosis in both HELLP and partial HELLP syndrome. Usually mother with altered liver functions received fresh frozen plasma and mother with low platelets $(<50000 / \mathrm{cu} \mathrm{mm})$ received platelet transfusion. Sepsis was mainly observed in referral patients with poor antenatal care. Maternal deaths were due to disease itself or its complication. A significant number of patients with HELLP and partial HELLP were referred from outside. This underlies the importance of awareness of diagnosis of both HELLP and partial HELLP syndrome and timely referral to tertiary care hospital for early and proper treatment.

\section{CONCLUSION}

HELLP and partial HELLP syndrome must be diagnosed as early as possible in pregnant or post-partum patient with preeclampsia. Present study suggests that all pregnant or post-partum women with hypertension should be investigated for complete blood counts, platelet count and liver enzyme along with all routine tests. This will help treating obstetrician to make an early diagnosis of partial HELLP or HELLP syndrome to allow early intervention for better feto-maternal outcome.

HELLP syndrome is severe than preeclampsia in term of maternal and perinatal outcome.

Partial HELLP syndrome is almost as grave as HELLP syndrome. Continues research work is required to calculate exact prevalence in Uttarakhand state, India. 
Funding: No funding sources

Conflict of interest: None declared

Ethical approval: The study was approved by the Institutional Ethics Committee

\section{REFERENCES}

1. Sharma JB. Hypertensive disorder of pregnancy. Text Book of Obstetrics. 2014;32(4):427.

2. Faridi A, Rath W. Differential HELLP syndrome diagnosis. Z Geburtshilfe Neonatol. 1996;200(3):8895.

3. Abbade JF, Peraçoli JC, Costa RA, Calderon ID, Borges VT, Rudge MV. Partial HELLP syndrome: maternal and perinatal outcome. Sao Paulo Medical Journal. 2002;120(6):180-4.

4. Guzel AI, Kuyumcuoglu U, Celik Y. Are maternal and fetal parameters related to perinatal mortality in HELLP syndrome? Archives of gynecology and obstetrics. 2011;283(6):1227-32.
5. Rakshit A, Lahiri S, Biswas SC, Dey R, Roy BR, Saha MM. A study to detect HELLP syndrome and partial HELLP syndrome among preeclamptic mothers and their impact on fetomaternal outcome. $\mathrm{Al}$ Ameen Journal of Medical Sciences. 2014;7(1)20-5

6. Satpathy HK, Satpathy C, Frey D. HELLP syndrome. The Journal of Obstetrics and Gynecology of India. 2009;59(1):30-40.

7. Rath W, Faridi A, Dudenhausen JW. HELLP syndrome. Journal of perinatal medicine. 2000;28(4):249-60.

8. Aydin S, Ersan F, Ark C, Arıoğlu Aydın Ç. Partial HELLP syndrome: maternal, perinatal, subsequent pregnancy and long-term maternal outcomes. Journal of Obstetrics and Gynaecology Research. 2014;40(4):932-40.

9. Haram K, Svendsen E, Abildgaard U. The HELLP syndrome: clinical issues and management. A Review. BMC pregnancy and childbirth. 2009;9(1):1.

Cite this article as: Tandon $\mathrm{A}$, Chaudhari $\mathrm{P}$, Gupta V, Ramola M. Feto-maternal outcome in patients with HELLP and partial HELLP syndrome: a prospective 10 year study in Shri Guru Ram Rai Institute of Medical and Health Sciences, Uttarakhand, India. Int J Reprod Contracept Obstet Gynecol 2016;5:3066-71. 